\title{
Civil Society: A New Social Movements in India
}

\author{
Dr. S. Kumar Swami* \\ Ex. Reader in Political Science, Kamala Nehru Women's College, Bhubaneswar - 9 \\ *Corresponding Author: Dr. S. Kumar Swami, Ex. Reader in Political Science, Kamala Nehru Women's \\ College, Bhubaneswar-9
}

\begin{abstract}
Civil is a precondition for the realization of true democracy. Civil society - a new social movements in India. Gandhi's Sarvodaya Movement, Bhoodan movement, Chipko movement, Appiko movement, Narmada BachaoAndolan, Anna Hazari's movement against corruption are some of the examples which emphasize the right of the common people to implement different welfare schemes and Government initiative for betterment of the people. It would encourage the citizens to fight for common cause and try to establish true democracy in India.
\end{abstract}

Keywords: Civil society, True democracy, Sarvodaya, Chipko Movement, Narmoda Bachao Andolan, People's movement.

\section{INTRODUCTION}

The concept of civil society has interesting history. It has always been a part of liberal democratic theories. The liberal notion conceives of civil society as a sphere independent of but to be protected by the state wherein the rights bearing individuals are free to pursine their private interests in free association with others. This definition reduces civil society to that of free market or free economy. Later liberals like J.S. Mill and Alexis De Tocqueville conceived civil society as a domain of social associations,, which would check the excesses of the state. They were concerned about the growing power of the state and held the view that without active social associations, even democracies could become despotic regimes, so a revival of and reconstruction of an active civil society supposed to be a precondition for the realization of true democracy and development.

\section{NEW SOCIAL MOVEMENTS IN INDIA}

The earliest of social movements in India could be traced to be the Gandhian effort of sarvodaya. Gandhi recognized the need for social change. Sarvodaya was the direct offshoot of Gandhi's constructive programme. According to Radhakrishnna, the ideological Paradigm of sarvodaya sought to create a stateless and classless society of Gram swarajya, establish the Principle of sharing voluntarily such as through Bhoodan and Gramdan, develop village industries and agro industrial communities and apply the Gandhian concept of trusteeship in industrial activities. Through it evoked much hope in the beginning the gross failure of Bhoodan in land redistribution through voluntary means has evaporated that hope.

Since 1970s a number of social movements emphasizing on a range of basic issues have to animate the sphere of civil society. But the people's movements, as they are called are the result of broader base people's responses to ecological or gender or caste conficts. The distinguishing feature of these movements is that they are not homogeneous and differ in their origins. In many cases the local initiatives merge and give rise to the formation of a large scale movement are the intervention of intellectuals backed with media support.

Some of the people's movements have been sustained over time, others are eruptions and die down after a while. Similarly some of the grassroots experiments represent seeds of change, while others are mere bubbles.

Now we shall look into some of the movements that have highlighted issues of great concern to people and ecology. Chipko deserves to be listed foremost them all. Chipko as a spontaneous 
movement started in the early 70s and got organized under the able leadership of sunderlal Bahuguna. It was ignited by the opposition of the people of the Tehri- Garhwal region to the felling of trees by outside contractors. In the Himalayan regions forests form an indispensable source of livelihood for the mostly tribal population living there. Chipko literally means "hugging the trees". Though the movement has not succeeded in all its endeavours, it has achieved some commendable victories. Chipko being a non- violent resistance movement embodies the Gandhian spirit of struggle. Chipko movement inspired green cover movements else wherein the country the most important being the Appiko movement in the eastern Ghats against the over felling of trees and covering forest lands with commercial trees replacing the natural ones. The slogan of chipko movement ecology is in economy.

Another major social movement has been that of Anna Hazare who has been fighting since more than two decades for bringing about transparency in bureaucratic apparatus of the state. His movement has changed his village Ralegon siddhi in Maharashtra into a model village. His movement emphasizes the right of the common people to know the information regarding government initiative and the implementation procedures of the welfare schemes.

Yet another important movement of the recent times is Narmada Bachao Andolan Samiti. This movement, led by Medha Patkar, has sensationalized the issue of building huge dams as a solution for growing stress on water resources. This movement is in opposition to the construction of nearly 3000 major and minor dams across the river Narmada.

There have been a number of other struggles prioritizing issues related to women dalit empowerment, land use and pollution related issues. Women's movements, through lacking a tradition equivalent to that of French and English feminist movements have reached a point where they are able to identify common cause with all those movements which would further the advancement of the values of democracy and sustainable development.

The new social movements are indicators of the pulse of the people that they are no longer ready to accept the developmental paradigms that keep them out and preclude their participation. They may not be concerned with the capturing of the state power through revolution yet they may be building consciously or unconsciously a countervailing power to the dominant state power. The new social movements also represent ways to humanize the larger macro developmental processes in order to demonstrate the fact that the modes of incorporation into the modern world at all levels could be altered. These movements also show how people cope with multiple and simultaneous crises and move on.

People's movements are emerging out of peculiar contradictions within societies and cultures in transition. They may also arise out of contradictions and weaknesses that appear in the role of the state and in the division of labour resulting from the intervention of transnational capital. The new social movements are also bringing about the horizontal integration of people instead of hierarchical integration. It is said that ecology movements constitute transnational, biophilic, universalized and moral movements. Their basic commitment and fundamental ideology not only transcend the human categories of caste, class, race, religion and nations but also the categories of species divisions and the divisions of the organic and inorganic world also. The movements are unique events which bring together, the otherwise divided humans on one platform around a single issue mobilizes them to struggle for brings born and unborn.

\section{CONCLUSION}

However there are innumerable other movements as well differing in degrees of mobilization, conscientisation and organization for development and democracy. All these initiatives may not always proceed in a uniform pattern of development. Within the political space available, there have been interventions in the socio- economic system. In case of smaller experiments, someone with an advanced consciousness initiates dialogue and a group activity, for example, landless labourer, poor women or a (youth) group trying to do something as a means of living or a social activity such as a health or environmental santitation programme, the process can move forward to become a seed or stay as a bubble until it brusts. Whereas all social movements after open to all. The movements are exclusive and have particular objectives rather than universal principles. 


\section{REFERENCES}

[1] Chandhoke, Neera, The conceits of civil society.2003.

[2] Kavirani, Sudipta and S. Khilmani, Civil Society; History and possibilities,2001

[3] Nadkarmi, M.V- Farmer's Movement in India, 1987.

[4] Shah, Ghanashyam-Social Movements and the state, 2002.

[5] Cook. T.E, and Margan P.M-Participatory democracy, 1971.

[6] Oakley, P- Strengthening civil society, concept and approaches, 2003.

[7] Hall, J.R-Civil Society; Theory, History, Comparison,2013.

[8] Y. Aiyar- Globalisation in India; civil Society Response, 2007.

[9] R. Munck- Civil Society; Myth and Prospect, 2004.

[10] Wooaback, D. and Selle, P- A social democratic model of civil society; changing images of civil society, 2008.

Citation: Dr. S. Kumar Swami. "Civil Society: A New Social Movements in India” International Journal of Political Science (IJPS), vol 5, no.4, 2019, pp. 48-50. doi: http://dx.doi.org/10.20431/2454-9452.0504007.

Copyright: (C) 2019 Authors. This is an open-access article distributed under the terms of the Creative Commons Attribution License, which permits unrestricted use, distribution, and reproduction in any medium, provided the original author and source are credited. 